\title{
Small business development and resource use in Russian regions
}

\author{
D.Yu. Fraymovich ${ }^{1} \bowtie$, M.A. Gundorova ${ }^{1}$, Z.V. Mischenko ${ }^{1}$, A.-M. Guzhov ${ }^{1}$, A.V. Sultanova ${ }^{2}$ \\ ${ }^{1}$ Vladimir State University n.a. Alexander and Nikolay Stoletovs, Vladimir, Russia; fdu78@rambler.ru \\ ${ }^{2}$ Samara Polytech, Samara, Russia
}

\section{ABSTRACT}

Relevance. The living standards in any country largely depend on how developed is this country's business sector. The latter, in its turn, relies on the availability and efficient use of resources. The problem that arises in this respect and that this study seeks to address is how to measure the resource potential available for the development of small businesses in order to choose the optimal strategy of stimulating this sector for this or that region. Research objective. The aim of this research is to study resources available to small businesses and their use in Russian regions. Data and methods. The set of indicators used in our analysis helps us measure the activity of small businesses in Russian federal districts. The key elements of the assessment are based on the official statistics and include the following: average labor productivity of small businesses, the unit turnover per small enterprise, the number of small firms per 10,000 people. Each of these indicators was analyzed by using the methods of mathematical statistics according to the three criteria: stability $(S)$; average values $(M)$; and the variability of the results $(V)$, which characterizes interregional differentiation within a federal district/country. Results. The article proposes a system of indicators for diagnosing small business development based on the concentration and performance of small-sized enterprises. The quantitative results of such analysis can be used for choosing strategies of small business development. Conclusion. There was a significant decline in entrepreneurial activity during the post-crisis period of 2017-2018 in Russia, which could be explained by the impact of foreign sanctions and the difficult economic situation in the country (inflation, a sharp rise in the price of resources, difficulties in communication with international partners, and the difficulty or even impossibility to adopt efficient technologies in a short time). As our analysis has shown, some of the Russian territories still have underutilized resource potential that can be used for stimulating small business development.

\section{KEY WORDS}

small business, region, resources, potential, efficiency, statistical characteristics

\section{Развитие малого бизнеса и использование его ресурсного потенциала в регионах России}

\author{
Д.Ю. Фраймович ${ }^{1} \bowtie$, М.А. Гундорова ${ }^{1}$, 3.В. Мищенко ${ }^{1}$, А.-М. Гужов ${ }^{1}$, А.В. Султанова ${ }^{2}$ \\ ${ }^{1}$ Владимирский государственный университет Александра Григорьевича \\ и Николая Григорьевича Столетовых, Владимир, Pоссия; e-mail:fdu78@rambler.ru \\ ${ }^{2}$ Самарский государственный технический университет, Самара, Россия
}

\section{АННОТАЦИЯ}

Актуальность. Уровень жизни в любой стране во многом зависит от того, насколько развит деловой сектор этой страны. Последнее, в свою очередь, зависит от доступности и эффективного использования ресурсов. Проблема, которая возникает в этой связи и которую пытается решить данное исследование, заключается в том, как измерить ресурсный потенциал, доступный для развития малого бизнеса, чтобы выбрать оптимальную стратегию стимулирования этого сектора для того или иного региона. Цель исследования. Целью исследования является изучение ресурсов, доступных малому бизнесу, и их использования в регионах России. Данные и методы. Сформированная в работе серия относительных индикаторов направлена на выявление активности малого бизнеса по федеральным округам страны. Базовыми элементами оценки на основе данных офици-

\section{КЛЮЧЕВЫЕ СЛОВА}

малый бизнес, регион, ресурсы, потенциал, эффективность, статистические характеристики 
альной статистики выступают: средняя производительность труда в малом бизнесе, удельный оборот на одно малое предприятие, число малых фирм на 10000 населения. Каждый из указанных индикаторов проанализирован с помощью применения методов математической статистики по 3-м критериям: устойчивости $(S)$; средним значениям $(M)$; вариативности результатов $(V)$, отражающей степень межрегиональной дифференциации в пределах Федерального округа/страны. Результаты. В работе предложена система показателей для диагностики деятельности сектора малого предпринимательства на основе системы показателей «концентрация-эффективность» и их статистических характеристик. Количественные значения полученных результатов служат основой для выбора направлений развития малого бизнеса в конкретной социально-экономической системе. Выводы. В посткризисный период 2017-2018 гг. в России наблюдался значительный спад предпринимательской активности, что можно объяснить влиянием внешних санкций и сложной экономической ситуацией в стране (инфляция, резкое удорожание ресурсов, трудности в общении с международными партнерами, а также сложность или даже невозможность внедрения эффективных технологий в короткие сроки). Как показал проведенный нами анализ, на некоторых территориях России все еще имеется недоиспользованный ресурсный потенциал, который может быть использован для стимулирования развития малого бизнеса.

\section{ДЛЯ ЦИТИРОВАНИЯ}

Fraymovich, D.Yu.,

Gundorova, M.A., Mischenko, Z.V., Guzhov, A.-M., Sultanova, A.V. (2021) Small business development and resource use in Russian regions. $R$-economy, $7(2), 88-99$. doi: $10.15826 /$ recon.2021.7.2.008

\section{Introduction}

In Russia in recent years, much scholarly attention has been given to how efficiently resources necessary for small business development are used. This problem is discussed in relation to the need to revive and stimulate this sector. Therefore, the research in this area is necessary to find ways to improve the performance of small businesses (including the sphere of innovation). There are, however, some inherent methodological difficulties such as the choice of indicators, the choice of a specific time lag or data verification.

Gradual digitalization of the country's economy, the use of end-to-end information technologies, and, as a result, the intensification of communications between businesses boost the country's entrepreneurial potential and reduce the costs. Therefore, it is important to describe the current trajectory of development of the small business sector, which is the most flexible sector in the country's economy.

Our study focuses on the resource potential of regional small businesses. Regional resource potential for the development of SMEs includes the following: the industrial structure of the regional economy; technological innovation to expand the range of activities of SMEs; and government support (Artemov et al., 2018). This set of elements can be expanded by adding human resources since labor efficiency affects the performance of economic entities and the regional economy as a whole.
Our aim is to study how small businesses in Russia use their resources. This aim has determined the following research objectives: to provide an overview of the methodological approaches to this problem; to create a system of indicators to assess the development of local small businesses; to test our methodology by using official statistical data; and, finally, to outline prospects for improving the efficiency of businesses.

The hypothesis of the research is there are significant variations in the indicators of entrepreneurial resource development across Russian federal districts.

This research seeks to analyze the data on Russian regions by looking at a set of chosen characteristics (concentration and efficiency of small businesses) and thus provide recommendations regarding the most efficient administration strategy of managing resources for small business development.

\section{Literature review}

Modernization, accelerated technological growth, improvement of the living standards and the changing institutional conditions depend entirely on the speed and quality of innovation in the business environment.

The policy of the Russian government is aimed at revitalizing regional systems by creating conditions for innovative development to ensure higher efficiency of businesses, better output and labor productivity, and thus raise the living standards in regions. population life quality. Thus, in their de- 
velopment, regional systems seek to develop their resource potential (Donichev, et al., 2018).

The development of technological innovation largely depends on the material and resource support of research and on the market conditions (Godoy, 2000). Many technological innovations are a result of deliberate effort made to increase productivity. Some part of the innovation, usually the most 'radical' one, is driven by intuition and creativity.

H. de Groot et al. (2009) claim that sustainable formation and development of a regional economic system relies on the active use of innovative resources. E.Lenchuk (2016) emphasizes that a complete inventory of the existing economic and industrial potential of the country is required in the initial phase in order to devise conceptual approaches to national technological development and to high-quality forecasting.

SMEs play a key role in economy and social development of any state because they help deal with the shortage of goods and services through intensive search for new business solutions. Moreover, SMEs create employment and serve as a source of tax revenue for the state budget.

According to L. Bliahman (2013), the main method of new industrialization is mass innovative entrepreneurship. SMEs can thus replace giant hierarchical corporations. Corporations have big research centers but they may be outplayed by chains of small firms which use informal relations based on flexible contracts, trust and fast response to customers' needs (Zaslavskaya, 2013).

The status of small business defines the strategic behavior of large and medium-sized businesses in terms of their investment decision-making (Cheberko, Mayevsky, 2013). Small businesses tend to be more flexible, especially if they use automatic lines, robots, CNC machines and machining centers, which helps them to stay on top of industry trends (Faltzman, 2019). Thus, the saturation of markets, intensification of competition in the small business sector and the improving living standards are the key trends in all developed countries.

Modern Russia does not have an effective mechanism for socio-economic growth yet due to the lack of a well-developed market with a normal competitive environment and effective development incentives. Such mechanism is usually created on the basis of the prevailing private ownership of SMEs (Aganbegyan, 2018). At the same time, in Russia, state ownership domi- nates over private one and oligarchic structures control the predominant part of private property while SMEs account for about one fifth.

It should also be noted that the problems, patterns and results of entrepreneurship development have been a much debated question in international research literature for a long time. For example, in 1979, American researcher, David L. Birch (1979), analyzed the statistics of small businesses for a ten-year period and published the results in his report "The Job Generation Process". It was shown that a significant part of the regional economic growth came from independent firms; on average about $60 \%$ of all jobs in the USA were created by companies with 20 or less workers, and about $50 \%$ of all jobs were created by independent entrepreneurs while large companies (with more than 500 workers) provided less than $15 \%$ of all jobs (Birch, 1979).

American economist A. Cooper (1985) showed the valuable contribution of incubator enterprises to the development of regional business enriched by new subsidiaries of successful parent companies (spin-offs). An illustrative example is the operator of the PayPal payment system to which large companies such as Tesla Motors, LinkedIn and others delegated the implementation of their (Rao, 2008).

There is research evidence that labor productivity and firm size are related, which contributes to scientific discussion about support of small and micro-enterprises only (Bartelsman et al., 2013; Linarello, Petrella, 2017; Wildnerova, Blochliger, 2019).

According to I. Domnina and L. Mayevskaya (2019), despite the large body of research on this problem, the role of SMEs in the socio-economic development of regions is still largely an underexplored question.

Experts from the Higher School of Economics (HSE, Moscow) have demonstrated the lack of longitudinal research (for a period of 20 years or more) on economic agents' activity and its connection to economic growth. To update the methodology and make the assessment more objective, the researchers propose the model "economic growth - business and consumer confidence" for the expert community based on official Rosstat data on eighty-five Russian regions and six basic economic sectors There is evidence of the significant potential of industries where entrepreneurial confidence is growing. The HSE's study uses a wide range of quantitative, mainly mathematical, 
analysis tools and covers a 23-year period. Other industries, even those where the activity is high but grows slowly or stagnates, are "catching up" with the leaders in the HSE's ranking of entrepreneurial optimism (Kitrar, Lipkind, 2020). An important advantage of the HSE's methodology is the use of a large body of data, both in the spatial and temporal dimension. On the other hand, this study uses Rosstat survey data, which may provide a somewhat distorted picture of the trends in the sphere of small business in Russia.

N. Yakushev (2020) puts the main emphasis on the technological effectiveness of entrepreneurship. It is necessary to develop a methodology for evaluation of the technological entrepreneurial activity and its parameters and compare the Russian and international experience. In this respect, it should be noted that there are several difficulties that will have to be addressed: there is a lack of official statistical data on this sector of economy and the use of expert assessments for such purposes will not provide an adequate and qualitative understanding about the real situation and dynamics of specific parameters which are necessary for competent decision-making.

Our analysis of the research literature has shown that in Russia there is a lack of state support for small businesses, strategic programs in this sphere should be adapted to the needs of different regions or federal districts; and, finally, it is necessary to update the assessment tools to trace the dynamics of small business and determine the growth points in Russian regions.

\section{Research methods}

The methodological framework for research on small businesses' resource potential is usually provided by econometric analysis methods. This method has been already tested (see, for example: Fraimovich et al., 2014).
Our study comprises the following steps: 1) development of consolidated indicators of quality that could be used to describe the current state of entrepreneurial activity in this or that territory; 2) selection of the parameters according to the available statistical data; 3 ) selection of the statistical characteristics of the measured parameters to identify the behavior of small businesses; 4) quantitative research based on the chosen parameters and databases; 5) devising recommendations for more efficient administration of small business development in Russian regions.

Our quantitative analysis is based on official statistics on small businesses in all regions and federal districts of the Russian Federation in 2011-2018.

We excluded the data from the lockdown period of the COVID-19 pandemic from our calculations due to the lack of updated information for later time intervals. However, in this case it is important to assess the performance of small businesses before the beginning of the lockdown period. This way we will be able to answer the following questions: 1) did the business sector develop in Russian regions before the pandemic? and 2) can the sluggish growth of the small business sector be explained by the adverse effects of the lockdown? The proposed methodology can be applied to the sphere of medium-sized and large businesses and for studies based on the data on other territories and countries.

The list of indicators is shown in Table 1.

All indicator systems are samples both in terms of the number of observations and the number of parameters. The proposed indicators reflect the general state of small business development in a region. These indicators rate this sector depending on the concentration of firms and their performance. The choice of these criteria - efficiency and concentration - and the key principles of statistical modelling have led us to to minimize the

Base indicators and methods of analysis of small business development in Russia

\begin{tabular}{|l|c|l|l|}
\hline \multicolumn{1}{|c|}{ Indicator } & Notation & \multicolumn{1}{|c|}{ Methods } & \multicolumn{1}{c|}{ Units } \\
\hline $\begin{array}{l}\text { 1. Average labor productivity in } \\
\text { small businesses }\end{array}$ & $l$ & $\begin{array}{l}\text { Small business turnover / Average number of em- } \\
\text { ployees in small enterprises }\end{array}$ & million rubles / person \\
\hline $\begin{array}{l}\text { 2. Unit turnover per small } \\
\text { enterprise }\end{array}$ & $q$ & $\begin{array}{l}\text { Turnover of small enterprises / Number of small } \\
\text { enterprises }\end{array}$ & million rubles / unit \\
\hline $\begin{array}{l}\text { 3. Number of small businesses } \\
\text { per 10,000 population }\end{array}$ & $n$ & (Number of small enterprises / Population) $\cdot 10,000$ & unit / 10,000 people \\
\hline
\end{tabular}

Source: the authors' calculations based on data from the statistical yearbook "Regions of Russia" published by the Federal State Statistics Service (Rosstat) http://www.gks.ru/wps/wcm/connect/rosstat main/ rosstat/ru/statistics/publications/catalog/ (Accessed data: March 28, 2021) 
number of partial values. For monitoring, Rosstat uses the following indicators: small business turnover (billion rubles); production of the main types of products by individual entrepreneurs (in natural units); the average number of employees (thousand people); the number of small enterprises (units); and population (thousand people). The correlation between the parameters provides an opportunity to reduce parsed dataset to 3 .

It was already mentioned that each of these indicators should be analyzed according to the following three criteria: stability $(S)$ in 2011-2018; mean value $(M)$ in the same period; result variability $(V)$ reflecting the interregional differentiation within the confines of the federal district/ country, for the last reporting year (2018). It is worth explaining that stability $(S)$ of a given function is defined by the time factor influence coefficient of the regression equation on condition that the significance level of its statistics $(p)$ does not go beyond 5\% (Donichev, et al., 2011). It is possible to obtain mean values $(M)$ by calculating the arithmetic mean of the 8 -year time interval results.

Finally, the variability of the indicators is calculated as quotient of the standard value deviation and the mean value. It is easy to perform these calculations by using the Excel program.

\section{Results}

The above-described calculations are based on the available official statistics for all Russian regions. Table 2 shows the average labor productivity of small businesses in federal districts in 2011-2018.
The Central Federal District is in the first place in terms of stability $(S)$ and mean value $(M)$. The "outsider" position of the Volga Federal District seems quite paradoxical: this district is traditionally famous for its powerful manufacturing sector (including the entrepreneurship manufacturing sector) and developed infrastructure.

The graph of small businesses' labor productivity $(l)$ of the Central Federal District in 2011-2018 is presented in Figure 1 and is calculated according to the following function: $l(t)=-66.83+0.68 t$. The stability value is 0.68 $(S)$ because of the high correlation coefficient of this regression equation $(r=0.93)$ and its optimal statistics $((p) \approx 0)$. The stability of other territories is studied in the same way.

The resulting variability $(V)$ situation is quite the opposite. The Central Federal District is characterized by the highest spread in variability indicators (0.41). The Volga Federal District and the Southern Federal District have the minimum spread in variability indicators (0.2 each). Resources allocation was uniform in small businesses across the regions of these districts in 2018.

The swing chart (Fig. 2) shows that in spite of the increasing median significance of labor productivity of the Central Federal District in 2016-2018, the interregional differentiation does not decrease. This fact appears alarming due to the overconcentration of resources (both labor and production) in a limited number of regions and the sluggish growth of the economically vulnerable territories.

Average labor productivity of small businesses in 2011-2018

\begin{tabular}{|c|c|c|c|c|c|c|c|c|c|c|c|}
\hline \multirow[t]{2}{*}{ Territories } & \multicolumn{8}{|c|}{ Year } & \multirow{2}{*}{$\begin{array}{c}S \\
(2011-2018)\end{array}$} & \multirow{2}{*}{$\begin{array}{c}M \\
(2011-2018)\end{array}$} & \multirow{2}{*}{$\begin{array}{c}V \\
(2018)\end{array}$} \\
\hline & 2011 & 2012 & 2013 & 2014 & 2015 & 2016 & 2017 & 2018 & & & \\
\hline Russia & 2.17 & 2.18 & 2.30 & 2.45 & 4.25 & 3.87 & 4.46 & 4.97 & 0.45 & 3.33 & 0.30 \\
\hline Central Federal District & 2.95 & 2.59 & 2.65 & 2.92 & 5.33 & 5.12 & 6.29 & 7.08 & 0.68 & 4.37 & 0.41 \\
\hline Northwestern Federal District & 1.91 & 2.03 & 2.08 & 2.17 & 5.18 & 4.09 & 4.56 & 4.95 & 0.51 & 3.37 & 0.30 \\
\hline Southern Federal District & 1.95 & 2.16 & 2.36 & 2.60 & 3.31 & 3.19 & 3.98 & 3.78 & 0.30 & 2.92 & 0.20 \\
\hline $\begin{array}{l}\text { North Caucasian Federal } \\
\text { District }\end{array}$ & 1.89 & 2.03 & 2.28 & 2.45 & 3.07 & 3.66 & 3.89 & 4.25 & 0.36 & 2.94 & 0.25 \\
\hline Volga Federal District & 1.63 & 1.84 & 2.02 & 2.09 & 3.29 & 2.79 & 2.95 & 3.33 & 0.25 & 2.49 & 0.20 \\
\hline Ural Federal District & 2.18 & 2.35 & 2.52 & 2.55 & 3.95 & 3.39 & 3.77 & 4.11 & 0.29 & 3.10 & 0.21 \\
\hline Siberian Federal District & 1.73 & 1.88 & 1.95 & 2.08 & 3.47 & 3.12 & 3.37 & 4.10 & 0.34 & 2.71 & 0.22 \\
\hline Far Eastern Federal District & 1.92 & 2.01 & 2.19 & 2.34 & 4.06 & 3.91 & 4.04 & 4.23 & 0.4 & 3.09 & 0.28 \\
\hline
\end{tabular}

Source: the authors' calculations based on data from the statistical yearbook "Regions of Russia" published by the Federal State Statistics Service (Rosstat) http://www.gks.ru/wps/wcm/connect/rosstat main/rosstat/ru/statistics/publications/catalog/ (Accessed data: March 28, 2021) 


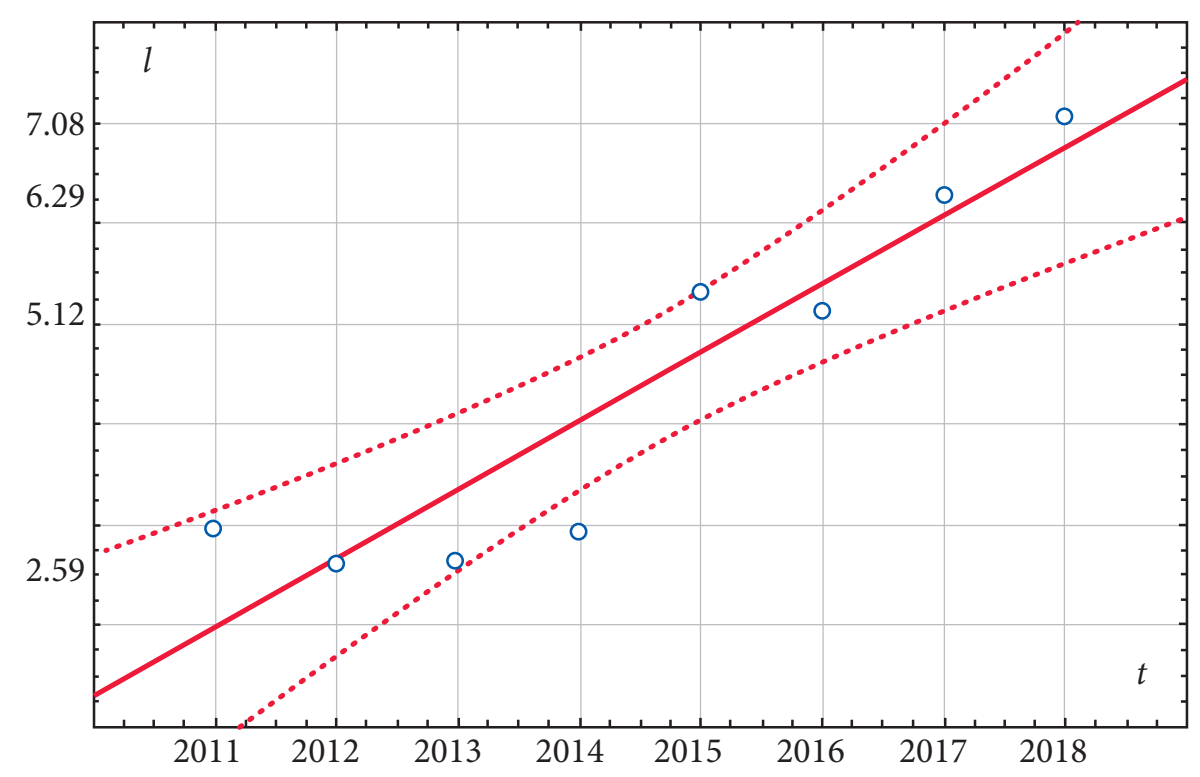

Figure 1. Labor productivity values scatter chart (l) in small businesses of the Central Federal District in 2011-2018 (l, million rubles/person; $t$, years)

Source: the authors' calculations based on data from the statistical yearbook "Regions of Russia" published by the Federal State Statistics Service (Rosstat)

http://www.gks.ru/wps/wcm/connect/rosstat main/rosstat/ru/statistics/publications/catalog/

(Accessed data: March 28, 2021)

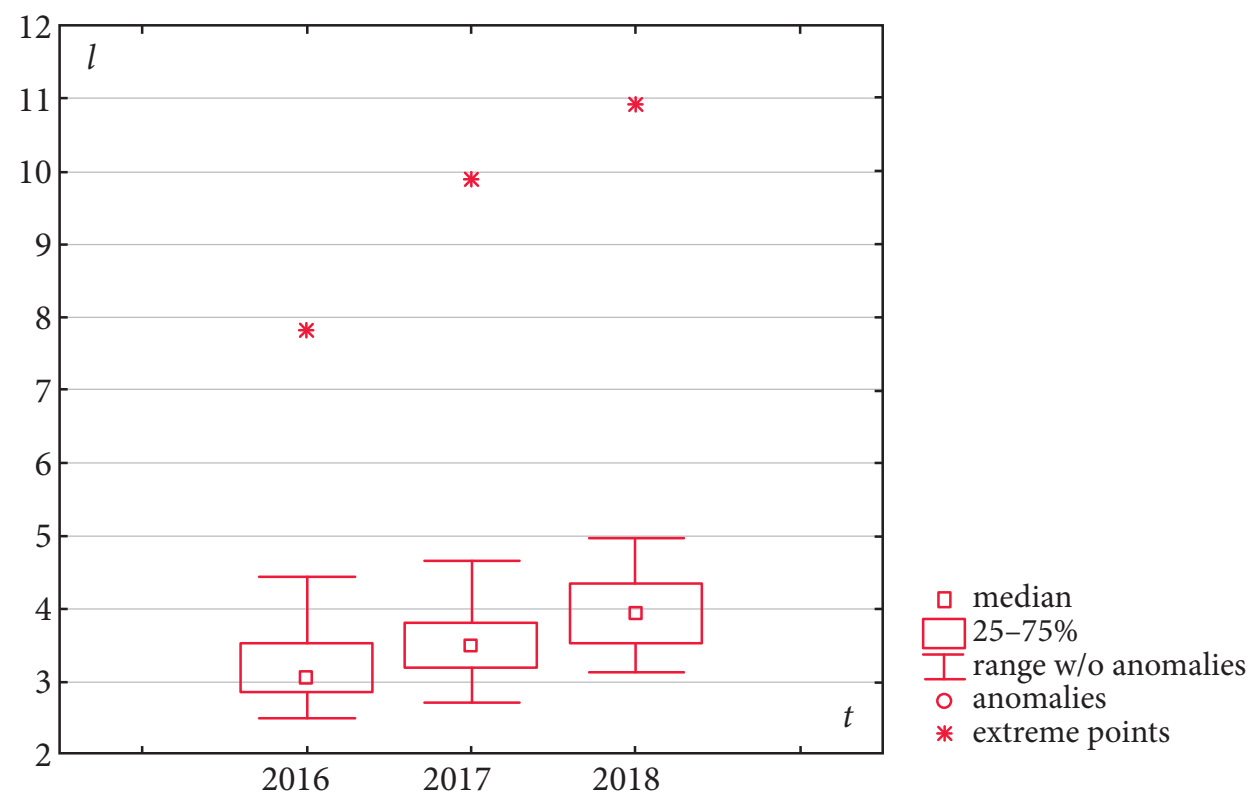

Figure 2. Labor productivity values swing chart (l) in small businesses of the Central Federal District in 2016-2018 (l, million rubles/person; $t$, years)

(notation: "Median" is the value separating the higher part (above this value) of the sample from the lower part.

In our case, the sample consists of 18 regions of the Central Federal District and is divided into two parts, each consistingo f 9 regions; "25\%-75\%" is a rectangle which corresponds to $25 \%$ and $75 \%$ quartiles; "Range without sampling" is the range of values $(l)$ which was obtained without accounting for observational outliers; "Extreme points" are the points which correspond to the extreme values in the sample)

Source: the authors' calculations based on data from the statistical yearbook "Regions of Russia" published by the Federal State Statistics Service (Rosstat)

http://www.gks.ru/wps/wcm/connect/rosstat main/rosstat/ru/statistics/publications/catalog/

(Accessed data: March 28, 2021) 
Regarding the second indicator - business turnover per small enterprise ( $q$ ), the North Caucasian Federal District and Far Eastern Federal District are the most successful in terms of stability $(S)$ (1.65 and 1.32, respectively). These results exceed those of the Central Federal District and Russia in general. The Northwestern Fede-ral District and the Southern Federal District are characterized by zero values in the stability indicator: business entities collect revenue in an unpredictable mode. Figure 3 shows the scatter chart of small business turnover $(q)$ in the Ural Federal District in 2011-2018.

The chart shows that the results $(q)$ of the Ural Federal District are quite different as evidenced by the significance level of the District's statistics $(p)$ $(p=0,092)$, which exceeds the threshold value $(0.05)$ and has a relatively low correlation coefficient $(r=0.63)$. Thus, there is no turnover stability in the Ural Federal District.

The Central Federal District demonstrates the maximum average unit turnover $(M q)$ (19.39 million rubles / unit), which is $25 \%$ higher than that of the North Caucasian Federal District (15.5 million rubles /unit) and the national average (15.01 million rubles/unit). The Siberian Federal District has the lowest result $(M q)$ in 2011-2018 (11.72).

The Volga Federal District shows the most optimal spread of the unit turnover interregio- nal indicators (variability - Vq) while the North Caucasian Federal District shows the maximum spread of indicators (0.69). It is half of the average Russian level (0.33).

Regarding the third indicator - the number of small enterprises per 10,000 (n) - it seems appropriate to note that the Central Federal District is ahead of the other regions in the group $\left(S_{n}=17,6\right)$ due to its stability in 2011-2018. In this indicator, the Central Federal District's level is twice higher than the national level $\left(S_{n}=8.97\right)$. The situation in the Far Eastern Federal District $(S=0)$ and in the North Caucasian Federal District $(S=0)$ is quite unpredictable.

Figure 4 illustrates a significant decline in business activity in the North Caucasian Federal District in the post-crisis period of 2017-2018. This decline is apparently related to the foreign sanctions and the deterioration of the general economic situation in the country (inflation, rise in resource prices, barriers to efficient communication with international partners, and the difficulty to adopt innovative technologies in a short period of time).

As for the average results $(M)$ of indicators $n$, the Central Federal District has the maximum value $\left(M_{n}=240\right)$ and North Caucasian Federal District has the minimum $\left(M_{n}=52\right)$.

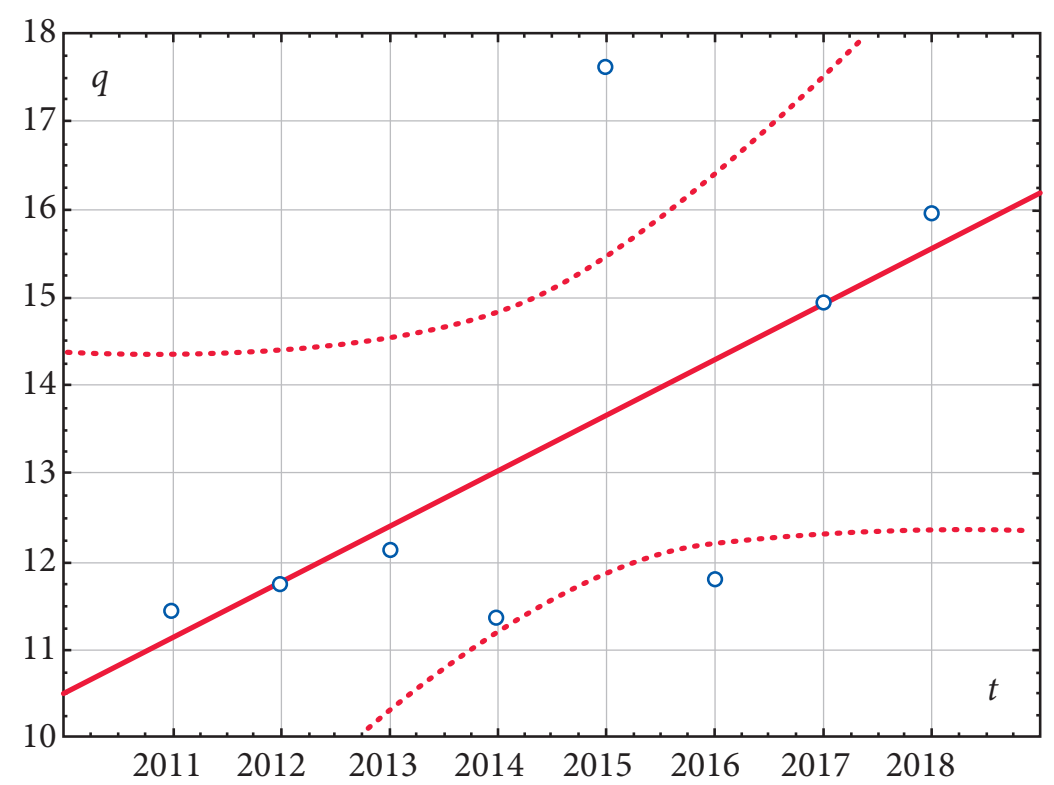

Figure 3. Scatter chart of small business turnover $(q)$ in the Ural Federal District in 2011-2018

( $q$, million rubles/person; $t$, years)

Source: the authors' calculations based on data from the statistical yearbook "Regions of Russia" published by the Federal State Statistics Service (Rosstat)

http://www.gks.ru/wps/wcm/connect/rosstat main/rosstat/ru/statistics/publications/catalog/

(Accessed data: March 28, 2021) 
The most balanced differentiation $(V)$ for this indicator is in the Volga Federal District $\left(V_{n}=0.29\right)$, and the highest, in the Northwestern Federal District $\left(V_{n}=0.56\right)$ and in the North Caucasian Federal District $\left(V_{n}=0.51\right)$.

The final calculation results of the resource potential of small businesses in districts in 2011-2018 are shown in Table 3.

As a result, we are going to use the case of the Central Federal District to illustrate how the pro- posed methodology can be applied. We are going to compare the District's values with national values (normative values) and the best results (referential values). The results for the Central Federal District for the first two sets of characteristics ( $S$ and $M$ ) should be compared with the similar ones for other territories. The order of the calculations of the variation which shows the growing inter-regional imbalances must be reversed. All calculations are presented in the petal diagram (Fig. 5).

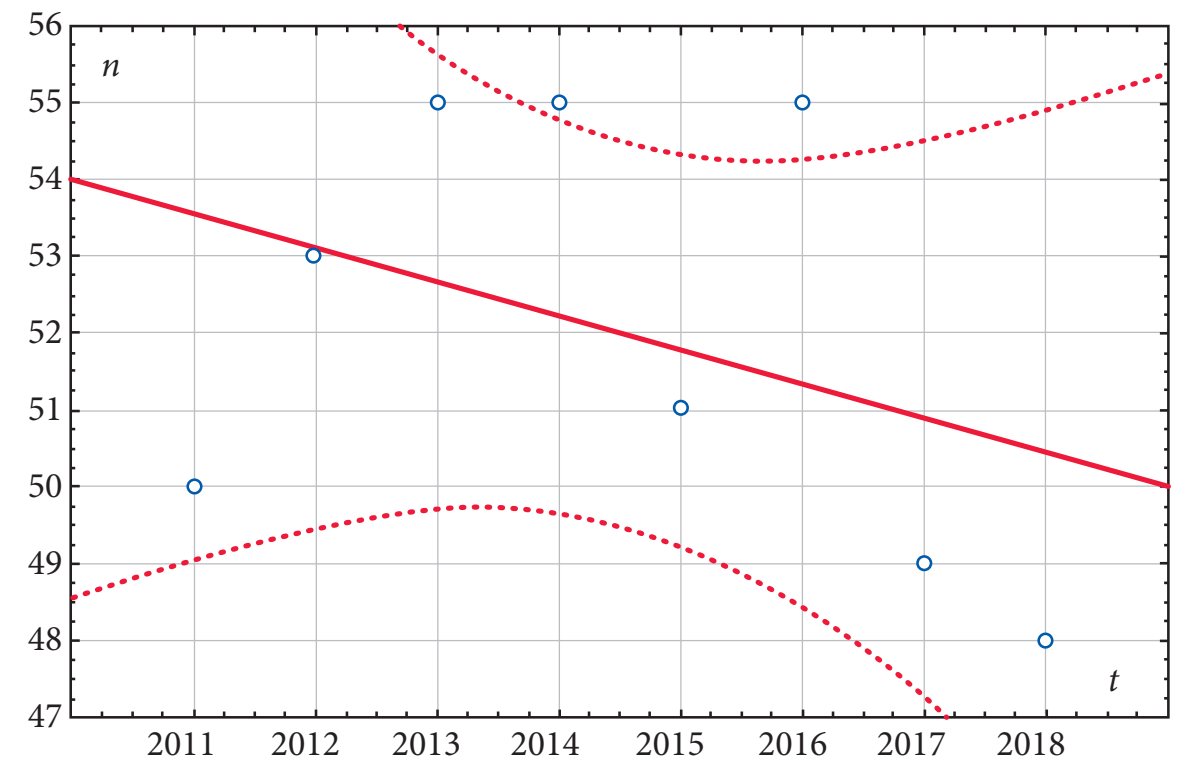

Figure 4. Scatter chart of the number of small enterprises per 10,000 of the North Caucasian Federal District in 2011-2018 (n, unit/10000 people; $t$, years)

Source: the authors' calculations based on data from the statistical yearbook "Regions of Russia" published by the Federal State Statistics Service (Rosstat)

http://www.gks.ru/wps/wcm/connect/rosstat main/rosstat/ru/statistics/publications/catalog/ (Accessed data: March 28, 2021)

Final calculation results of the resource potential of small businesses

Table 3 in federal districts in 2011-2018

\begin{tabular}{|l|c|c|c|c|c|c|c|c|c|}
\hline \multirow{2}{*}{ Territories } & \multicolumn{3}{c}{$\boldsymbol{S}$ in $\mathbf{2 0 1 1 - 2 0 1 8}$} & \multicolumn{2}{c|}{$\boldsymbol{M}$ in 2011-2018 } & \multicolumn{2}{c|}{$\boldsymbol{V 2 0 1 8}$} \\
\cline { 2 - 10 } & $\boldsymbol{p}$ & $\mathbf{q}$ & $\boldsymbol{n}$ & $\boldsymbol{p}$ & $\boldsymbol{q}$ & $\boldsymbol{n}$ & $\boldsymbol{p}$ & $\mathbf{q}$ & $\boldsymbol{n}$ \\
\cline { 2 - 10 } & $\mathbf{1}$ & $\mathbf{2}$ & $\mathbf{3}$ & $\mathbf{4}$ & $\mathbf{5}$ & $\mathbf{6}$ & $\mathbf{7}$ & $\mathbf{8}$ & $\mathbf{9}$ \\
\hline Russia & 0.45 & 1.15 & 8.97 & 3.33 & 15.01 & 158.21 & 0.30 & 0.33 & 0.48 \\
\hline Central Federal District & 0.68 & 1.25 & 17.6 & 4.37 & 19.39 & 184.05 & 0.41 & 0.19 & 0.44 \\
\hline Northwestern Federal District & 0.51 & 0 & 8.98 & 3.37 & 12.79 & 240.04 & 0.30 & 0.21 & 0.56 \\
\hline Southern Federal District & 0.30 & 0.94 & 3.65 & 2.92 & 14.03 & 119.29 & 0.20 & 0.31 & 0.32 \\
\hline North Caucasian Federal District & 0.36 & 1.65 & 0 & 2.94 & 15.50 & 52.00 & 0.25 & 0.69 & 0.51 \\
\hline Volga Federal District & 0.25 & 0.61 & 7.51 & 2.49 & 13.37 & 138.15 & 0.20 & 0.14 & 0.29 \\
\hline Ural Federal District & 0.29 & 0 & 8.06 & 3.10 & 13.37 & 171.19 & 0.21 & 0.20 & 0.37 \\
\hline Siberian Federal District & 0.34 & 1.06 & 5.78 & 2.71 & 11.72 & 154.96 & 0.22 & 0.22 & 0.44 \\
\hline Far Eastern Federal District & 0.40 & 1.32 & 0 & 3.09 & 13.79 & 156.78 & 0.28 & 0.27 & 0.38 \\
\hline
\end{tabular}

Source: the authors' calculations based on data from the statistical yearbook "Regions of Russia" published by the Federal State Statistics Service (Rosstat) http://www.gks.ru/wps/wcm/connect/rosstat main/rosstat/ru/statistics/publications/catalog/ (Accessed data: March 28, 2021) 
As can be seen from the graph, the Central Federal District exceeds the average Russian values in almost all normative indicators (except for 7). The reference results are higher than the results of this district from 6 to 9 positions. At the same time, the highest labor productivity interregional stratification $(V p-7)$ is in the Central Federal District. There is significant territorial polarization and concentration of the main production resources in Moscow agglomeration. These transformations significantly reduce the resource potential of peripheral areas by causing economic and social tensions.

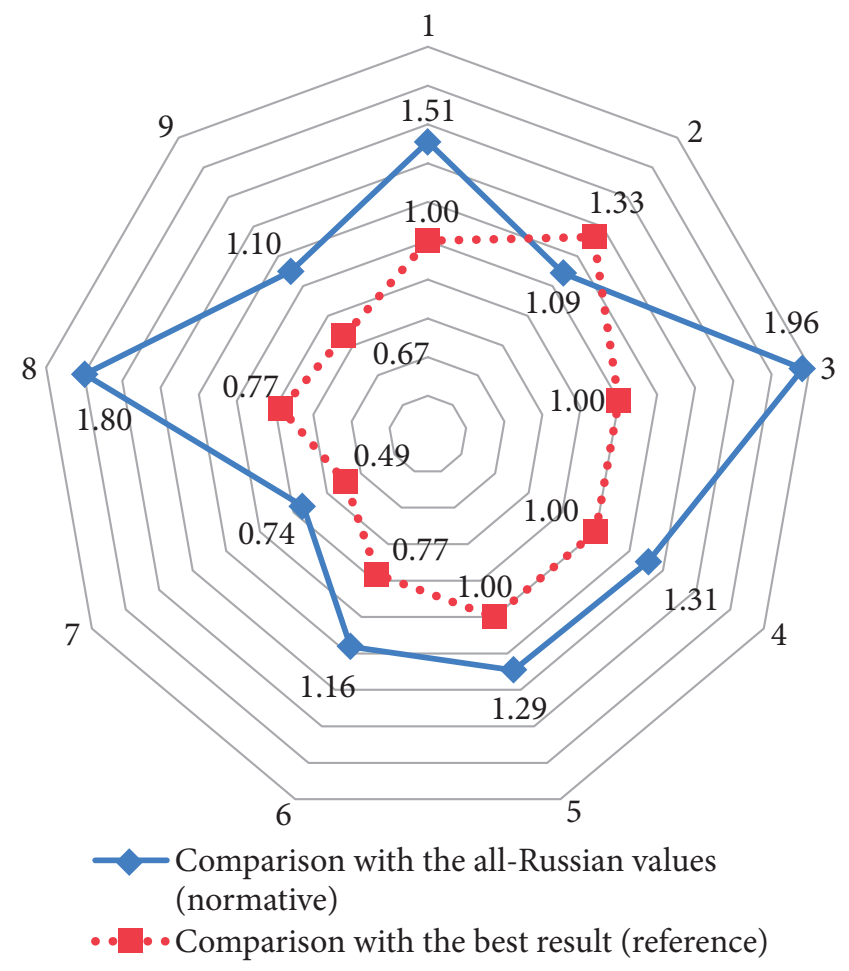

Figure 5. Comparison of the entrepreneurial potential of the Central Federal District with the normative and referential values in indicators (1-9)

Results of our analysis agree with the research evidence regarding the trends and prospects of business development in Russia. For example, Y. Mirkin (2020) claims that every large business cooperates with small and medium-sized suppliers. There are no large business and suppliers in the Russian Federation. The dependence on technology imports, equipment facilities, and raw materials is very high.

R. Greenberg argues that the share of small businesses (20\% of GDP in comparison to $60-80 \%$ in Western countries) is explained by the fact that the share of large diversified businesses in Russia is very small. In developed countries, such businesses give orders to smaller enterprises for making components and parts. Business in general, and small business in particular cannot be profitable until the country's economic development undergoes some profound changes (Greenberg, 2020).

$\mathrm{N}$. Ivanova (2019) contends that since the government is cutting its spending on the stimulation of innovation in the country, it is necessary to stimulate the development of corporate $\mathrm{R} \& \mathrm{D}$ centres, laboratories and high-tech start-ups and to encourage businesses to reorient from importing technological solutions towards creation and implementation of their own R\&D programs (transition from catch-up development whose possibilities are low because of the sanctions to more proactive strategies.)

V. Faltsman (2019) believes that a municipality, the head of this municipality and regional administration should be made responsible for the growth of the turnover of SMEs. The growth in the turnover accompanied by a reduction in state subsidizing ought to be the main criterion for assessing the quality of local and regional administrative work. Even though such factors as the results of election campaigns and the creation of a favorable investment climate are important, they cannot be used as such criteria. Natural rent as a source of subsidies is decreasing. Funds for the redistribution and interregional transfer of finance are diminishing progressively. Every municipality and region within resource-rich Russia ideally must become self-sufficient and provide for itself. Of course, the corresponding adjustments should be made to the Tax Code. The realization of the initiative described by Faltsman may, however, be impeded by the current legislation and by the lack of authority of the corresponding local governmental agencies.

M. Mirkin claims that the economic model and the macro-conditions for entrepreneurship must be changed to develop SMEs. After that, businesses should be stimulated with the help of such mechanisms as improved credit availability and lower interest rates; fiscal incentives for growth and modernization; maximum facilities for direct foreign investment; smaller tax burden; budget investments (e.g. by increasing public debt to $30-35 \%$ of GDP); accelerated depreciation; and so on (Mirkin, 2020).

Bessonova et al., who have studied the role of the business sector in Russia and found that the current situation is rather alarming, believe that 
the mechanisms for effective redeployment of resources should have a key role in the acceleration of labor productivity growth. In other words, there should be market conditions for new enterprises to be able to expand, hire new employees and increase labor productivity. It is also necessary to create an opportunity for enterprises without sufficient development potential to leave the market and for their employees to move to companies with a high level of labor productivity (Bessonova et al., 2020).

Zemtsov and his colleagues (2020) explain that business competition between regions and cities is necessary for the development of SMEs. Another necessary change is the reform of the fiscal system: the tax revenue collected by local governments should be used to support the business sector, in particular to co-finance the development of institutions that would provide entrepreneurs with "soft" services, equipment and capital, and to support local initiatives (through participatory budgeting). Tax incentives must be created to solve local problems and to increase the prestige of entrepreneurship (Zemtsov et al., 2020).

The above-described measures should be implemented as soon as possible since any delay may cause irreversible economic consequences and impede the country's socio-economic growth.

\section{Conclusion}

The use of territorial potential may be optimized by addressing the problem of regional disparities in Russia. This result might be achieved through micro-management and by increasing the amount of federal subsidies to lagging regions. It is, however, important to note that in some indicators the regional disparities may be quite small for some districts although the overall business performance in this district may be unsatisfactory. Thus, it would make sense to use the data on specific districts as well as the national statistics.

The proposed indicators and their statistical characteristics describe the situation in the regions within a certain federal district regarding the average level of small business development, its differentiation and stability. This allows us to identify the regional stratification level, and find the points of small business growth of the socio-economic system under examination. We propose the following strategies for entrepreneurial development within the selected system of indicators and their statistical characteristics:

1) administration should use the arithmetical averages of the indicators (concentration and performance of small-sized businesses) since such parameters are easy to control. Financial instruments applied to a limited number of entities might provide the best results at minimum costs;

2) administration oriented towards the level of interterritorial differentiation and providing support primarily to lagging regions;

3) administration aimed to ensure a positive stable growth. This strategy will help avoid fast transformations and preserve the existing stratifications. This strategy was chosen to select regions and small businesses whose goal is a long-term planned development in the most promising economic areas with long payback periods, stable consumer demand, and long-term positive social transformations;

4) a combination of administrative methods, which implies the improvement of several statistical characteristics, for example, synchronization of long-term sustainable growth and reduced stratification. In this case, it is necessary to select regions with greater resources, which will help reduce regional disparities while ensuring the general stability.

Each of the above-described strategies has some advantages and disadvantages. For example, the fourth strategy may lead to a reduction in the number of bankruptcies among small firms, a reduction in regional unemployment, a reduction in social tension, but it will not provide a significant increase in the benchmarks of stability and average economic values due to the lack of resources in Russia and, therefore, will not be able to improve all statistical characteristics simultaneously. As for governmental decision-making in Russia in relation to small businesses, it can be said that economic support is given mostly to the "strongest" regions. It leads to an increase in the average values of the parameters under consideration. Stability indicators, however, may slightly improve but the disparities in the regional business system will increase.

The choice of a strategy for stimulating small business development in Russian regions, especially if the available resources are scarce, should be based on the stimulation of one group of statistical indicators while the values of the others will decrease. We propose economic instruments for implementation of strategic decisions for small 
business development in the Russian Federation based on the system of indicators and their statistical characteristics.

The proposed approach can be used to determine how effectively the entrepreneurial potential of a territory is being used. Regional and local authorities can use our research findings to devise strategic programs for business development and support. The universal indicator system described in this study may also be of interest to high-tech incubators and innovation clusters as it can be applied to identify modernization trends, assess the efficiency of economic development and help devise new, more productive solutions.

\section{References}

1. Artemova, O.V., Logacheva, N.M., \& Nesterenko, I.Yu. (2018). Resources for developing regional small and medium-sized entrepreneurship. Society and Power, 2 (70), 48-55. (In Russ.)

2. Donichev, O.A., Fraimovich, D.Yu., \& Grachev, S.A. (2018). Regional system of economic and social factors in the formation of innovation development resources. Economic and Social Changes: Facts, Trends, Forecast, 3, 84-99. (In Russ.) doi: 10.15838/esc.2018.3.57.6

3. Godoe, H. (2000). Innovation regimes, R\&D and radical innovations in telecommunications. Research Policy, 29, 1033-1046. doi: 10.1016/S0048-7333(99)00051-7

4. de Groot, H.L.F., Poot, H.J., \& Smit, M.J. (2009). Agglomeration, innovation and regional development: Theoretical perspectives and meta-analysis. In R. Capello, \& P. Nijkamp (Eds.) Handbook of regional growth and development theories, pp. 256-281.

5. Lenchuk, E.B. (2016). National technology initiative - strategic vector of Russia's industrial policy. International Journal of Management Theory and Practice, 2, 8-19. (In Russ.)

6. Blyakhman, L.S. (2013). New industrialization: essence, political and economic foundations, socio-economic prerequisites and support. Problems of Modern Economics, 4, 44-53. (In Russ.)

7. Zaslavskaya, T. (2013). Socio-Economics as an Urgent basis of interdisciplinary integration. Voprosy Ekonomiki, 5, 144-150. (In Russ.) doi: 10.32609/0042-8736-2013-5-144-150

8. Cheberko, E.F., \& Mayevsky, A.V. (2013). The development of the small business sector as a factor in increasing the investment attractiveness of the region. Economics and Management, 8 (94), 22-28. (In Russ.)

9. Faltzman, V.K. (2019) Problems of forecasting small and medium-sized businesses. Studies on Russian Economic Development, 1, 16-22. (In Russ.) doi: 10.1134/S1075700719010064

10. Aganbegyan, A.G. (2018). On the way to a civilized market. Bulletin of Institute of Economy of the Russian Academy of Sciences, 1, 7-26. (In Russ.)

11. Birch, D.L. (1979). The Job Generation Process. Cambridge, MA: MIT Program on Neighborhood and Regional Change.

12. Cooper, A. (1985). The Role of Incubator Organizations in the Founding of Growth-Oriented Firms. Journal of Business Venturing, 1(1), 75-86. doi: 10.1016/0883-9026(85)90008-4

13. Rao, A. (2008). How to Grow Innovation Culture in Genesee Valley. Rochester Business Journal. Retrieved from https://rbj.net/2008/08/15/how-to-grow-innovation-culture-in-genesee-valley/

14. Bartelsman, E., Haltiwanger, J., \& Scarpetta, S. (2013). Cross-country differences in productivity: The role of allocation and selection. American Economic Review, 1, 305-334. doi: 10.1257/ aer.103.1.305

15. Linarello, A., Petrella, A. (2017). Productivity and reallocation: evidence from the universe of Italian firms. International Productivity Monitor, 32, 116-136. doi: 10.2139/ssrn.2910391

16. Wildnerova, L., Blöchliger, H. (2019). What makes a productive Russian firm? A comparative analysis using firm-level data. OECD Economics Department Working Papers, No. 1592.

17. Domnina, I.N., \& Mayevskaya, L.I. (2019). Place and role of small business in the socio-economic development of the regions of Russia: new tasks of state support. Bulletin of Institute of Economy of the Russian Academy of Sciences, 3, 66-82. (In Russ.)

18. Kitrar, L., \& Lipkind, T. (2020). Analysis of the relationship of the indicator of economic sentiment and GDP growth. Economic Policy, 6, 8-41. (In Russ.) doi: 10.18288/1994-5124-2020-6-8-41

19. Yakushev, N.O. (2020). Technological entrepreneurship in Russia: evaluation problems. Territorial Development Issues, 3, 1-13. (In Russ.) doi: 10.15838/tdi.2020.3.53.3 
20. Fraimovich, D.Yu., Mishchenko, Z.V., \& Gundorova, M.A. (2014). System of economic and mathematical indicators for making decisions to stimulate small business of the federal district. Management Issues, 6 (31), 100-109. (In Russ.)

21. Donichev, O.A., Mishchenko, Z.V., \& Fraymovich, D.Yu. (2011). The system of economicmathematical indicators in assessment of modernization capacity of regions of the federal district. Financial Analytics: Science and Experience, 44, 42-49. (In Russ.)

22. Mirkin, Y.M. (2020) Stimulation of the development of small and medium-sized businesses: macro conditions, international experience. Scientific Works of the Free Economic Society of Russia, 1, 98-113. (In Russ.)

23. Greenberg, R.S. (2020) Strategy for the socio-economic development of Russia: a conversation for the future. Scientific Works of the Free Economic Society of Russia, 4, 28-33. (In Russ.)

24. Ivanova, N.I. (2019). Science funding. The Journal of the New Economic Association, 1(41), 195-201. doi: 10.31737/2221-2264-2019-41-1-8

25. Bessonova, E.V. Morozov, A.G., Turdyeva, N.A., \& Tsvetkova, A.N. (2020). Opportunities to accelerate productivity growth: The role of small and medium-sized enterprises. Voprosy Ekonomiki, 3, 98-114. (In Russ.) doi: 10.32609/0042-8736-2020-3-98-114

26. Zemtsov, S.P., Chepurenko, A.Yu., Barinova, V.A., \& Krasnoselsky, A.N. (2020). A new entrepreneurial policy for Russia after the 2020 crisis. Voprosy Ekonomiki, 10, 44-67. (In Russ.) doi: $\underline{10.32609 / 0042-8736-2020-10-44-67}$

\section{Information about the authors}

Denis Yu. Fraymovich - Professor of Economics, Vladimir State University n.a. Alexander and Nikolay Stoletovs (79 Gorkogo St., 600005, Vladimir, Russia); e-mail: fdu78@rambler.ru

Marina A. Gundorova - Associate Professor of Economics, Vladimir State University n.a. Alexander and Nikolay Stoletovs (79 Gorkogo St., 600005, Vladimir, Russia); e-mail: mg82.82@mail.ru

Zorislav V. Mischenko - Associate professor of Technical Sciences, Vladimir State University n.a. Alexander and Nikolay Stoletovs (79 Gorkogo St., 600005, Vladimir, Russia) ; e-mail: zvm2002@ rambler.ru

Anna-Maria. Guzhov - Student, Vladimir State University n.a. Alexander and Nikolay Stoletovs (79 Gorkogo St., 600005, Vladimir, Russia); guzhov.anna.2001@mail.ru

Alexandra V. Sultanova - Associate Professor of Economics, Samara Polytech (244 Molodogvardeyskaya st., Samara, Russia); e-mail: sultanovaav@mail.ru

ARTICLE INFO: received February 6, 2021; accepted April 12, 2021

\section{Информация об авторах}

Фраймович Денис Юрьевич - доктор экономических наук, доцент, профессор кафедры экономики инноваций и финансов, Владимирский государственный университет имени Александра Григорьевича и Николая Григорьевича Столетовых (600005, Россия, г. Владимир, ул. Горького, 79); e-mail: fdu78@rambler.ru

Гундорова Марина Александровна - кандидат экономических наук, доцент кафедры экономики инноваций и финансов, Владимирский государственный университет имени Александра Григорьевича и Николая Григорьевича Столетовых (600005, Россия, г. Владимир, ул. Горького, 79); e-mail: mg82.82@mail.ru

Мищенко Зорислав Владимирович - кандидат технических наук, доцент, Владимирский государственный университет имени Александра Григорьевича и Николая Григорьевича Столетовых (600005, Россия, г. Владимир, ул. Горького, 79); e-mail: zvm2002@rambler.ru

Гужов Анна-Мария, студент группы ЭБк-119, Владимирский государственный университет имени Александра Григорьевича и Николая Григорьевича Столетовых (600005, Россия, г. Владимир, ул. Горького, 79); e-mail: guzhov.anna.2001@mail.ru

Султанова Александра Васильевна - кандидат экономических наук, доцент кафедры «Экономика и управление организацией», Самарский государственный технический университет (443100, г. Самара, ул. Молодогвардейская, 244); e-mail: sultanovaav@mail.ru

ИНФОРМАЦИЯ О СТАТЬЕ: дата поступления 6 февраля 2021 г.; дата принятия к печати 12 апреля 2021 г. 